\title{
Removal of Two Needles from the Liver and Axillary Region Using Ultrasound: A Case Report with Current Literature Review
}

\author{
Karaciğer ve Aksiller Bölgeden Ultrasonografi Yardımılla Iki Iğnenin Çıkarılması: \\ Güncel Literatür Taraması ile Birlikte Olgu Sunumu \\ (1) Sabri Demir, (1) Gülşah Bayram Ilıkan*, (1) Ahmet Ertürk, (1) Vildan Selin Şahin, \\ (1) Can Ihsan Öztorun**, (1) Doğuş Güney, (1) Elif Emel Erten, (1) Müjdem Nur Azılı**, \\ (1) Emrah Şenel** \\ Ankara Bilkent City Hospital, Clinic of Pediatric Surgery, Ankara, Turkey \\ ${ }^{*}$ Ankara Bilkent City Hospital, Clinic of Pediatric Radiology, Ankara, Turkey \\ ${ }^{* *}$ Ankara Yıldırım Beyazıt University Faculty of Medicine, Department of Pediatric Surgery, Ankara, Turkey
}

Abstract

Foreign body (FB) ingestion is a serious problem in children. A small number of the FBs swallowed migrate from the gastrointestinal tract to the peritoneal cavity or solid organs in the abdomen such as the liver. Imaging techniques, including fluoroscopy and ultrasound (US), are used perioperatively for their surgical removal. In prolonged interventions, the radiation emitted during fluoroscopy is undesirable for both healthcare workers and pediatric patients. In this case report, we share our clinical experience of removing two sewing needles, one from the liver and one from the left axillary region, from an 11-yearold male, with the guidance of perioperative US.

Keywords: Foreign body, children, ultrasound, liver, axillary region

\begin{abstract}
Yabancı cisimlerin (YC) yutulması çocuklarda ciddi bir sorundur. Az sayıda yabancı cisim yutulduktan sonra gastrointestinal sistemden periton boşluğuna veya karın içinde bulunan karaciğer gibi solid organlara göç eder. Bu YC'lerin cerrahi olarak çıkarılmalarında floroskopi ve ultrasonografi (US) gibi görüntüleme teknikleri kullanılmaktadır. Uzun süren müdahalelerde, floroskopi sırasında ortama yayılan radyasyon hem sağlık personeli hem de çocuk hastalar için istenmeyen bir durumdur. Bu olgu sunumunda, 11 yaşında bir erkek çocuğundan, biri karaciğerden diğeri sol aksiller bölgeden iki dikiş iğnesinin US yardımıyla çıkarılmasıyla ilgili klinik deneyimimizi paylaşmayı amaçladık.
\end{abstract}

Anahtar Sözcükler: Yabancı cisim, çocuklar, ultrasonografi, karaciğer, aksiller bölge

\section{Introduction}

Foreign body (FB) ingestion in children is a common cause of presentation to emergency centers. Although it is seen in all ages, it is most common in children between 6 months and 6 years of age $(1,2)$. In $80-90 \%$ of the cases, the ingested FB is spontaneously eliminated with stool without the need for any intervention. In the remaining $10-20 \%$ of cases, ingested FBs are removed endoscopically, and only $1 \%$ require open surgical intervention as a result of perforation, obstruction, or abscess formation (3).
Rarely, sharp ingested objects such as sewing needles and toothpicks can migrate from the gastrointestinal tract to organs such as the liver, pancreas, and heart and cause complications in those organs (4). These objects migrate very rarely into the liver; fewer than forty cases (adults and children) have been reported in the literature (5). Synchronous presence of two sewing needles in two different organs is very rare. Here, we present an 11-year-old pediatric patient who had two sewing needles synchronously in his liver and the left axillary region, 
which were removed with the assistance of perioperative ultrasonography (US).

\section{Case}

An 11-year-old male patient who had no previous complaints presented to the emergency room with pain in his left armpit and chest. Physical examination was normal. X-ray, US, and computed tomography images showed a $5 \mathrm{~cm}$-long sewing needle in the right lobe of the liver transversely, extending to the left lobe and adjacent to the portal vein. In the left axillary region, two adjacent $2 \mathrm{~cm}$-long metal FBs were detected within the fat layers (Figures $1 \mathrm{~A}$ and $1 \mathrm{~B}$ ). There was no history of FB ingestion in the patient's anamnesis, but his mother stated that the patient had been playing with sewing needles and fabric sewing pieces up until two years ago. It was not understood how the FBs settled in the left axilla. The patient's laboratory tests were normal. Written and verbal informed consent was obtained from the parents of the patient to perform and to report this operation. Surgical removal of the FBs was planned. First, the location of the FBs in the left axilla was determined and marked using US. The skin was then incised at that point. Two adjacent and rusted $\mathrm{FBs}, 2 \mathrm{~cm}$ and $2.5 \mathrm{~cm}$ in length and surrounded by a fibrous sheath, were removed (Figure $1 \mathrm{C}$ ). It was observed that the FBs were two pieces of a broken sewing needle (Figure 1D). Subsequently, the abdomen was then entered through a right subcostal incision. The location of the FB was determined intraoperatively over the liver with an 18-G biopsy needle under US guidance (Figures 2A and 2B). On the right-lateral face of the liver, from the lateral side of the biopsy needle, a $1 \mathrm{~cm}$ entry hole was opened in the liver capsule with a cautery, through which a long

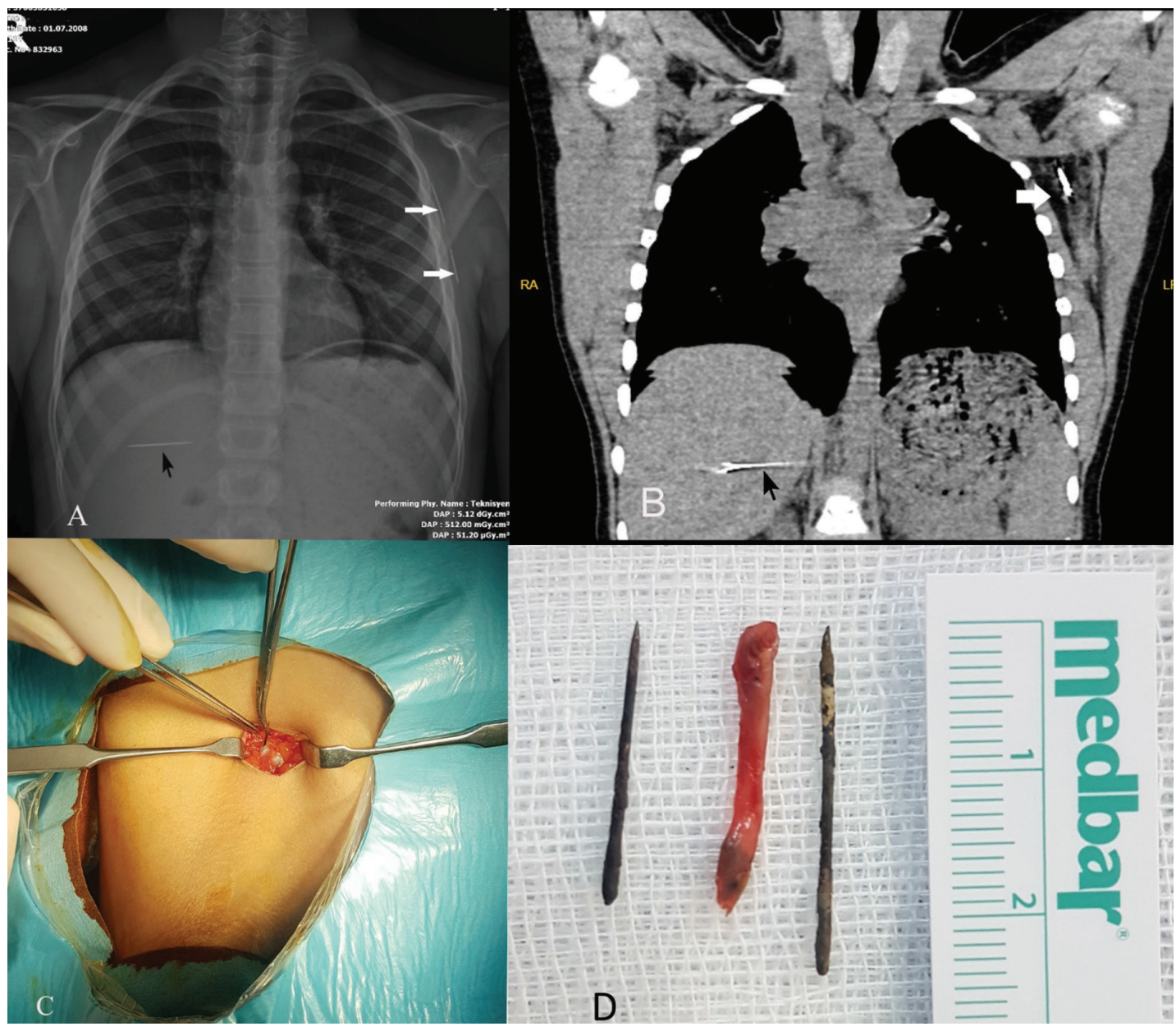

Figure 1. A) The appearance of foreign bodies in the liver (black arrow) and left axillary region (white arrows) in X-ray. B) Foreign bodies are seen in CT section (black arrow in liver, white arrow in axillary region). C) Removal of sewing needle pieces located in the left axillary region by the guidance of the ultrasonography. D) Foreign bodies removed from the left-axillary region and fibrous sheat in which a foreign body is removed are seen

CT: Computed tomography 
clamp was inserted (Figures 2C and 2D). The needle, located adjacent to the hepatic vein, was caught by the tip under US guidance (Figure 2E) and carefully removed. It was observed that the rusted sewing needle was about $4.5 \mathrm{~cm}$ long (Figure 2F). The liver entry hole was closed using 2-0 polyglactin 910 suture. The patient had no postoperative bleeding or bile leak; oral feeding was started on the second day and discharge was on the sixth day. No pathology was detected in the first-, third-, and six-month follow-ups.

\section{Discussion}

Normally, most of FBs swallowed are expelled spontaneously with stool without any complications within one week. However, less than $1 \%$ leave the gastrointestinal tract and migrate to the peritoneal cavity or other organs, such as the liver and pancreas, and require surgical (open or laparoscopic) removal $(6,7)$. FBs located close to the liver surface can be removed laparoscopically with the guidance of intraoperative US (8).
FBs penetrating outside the gastrointestinal tract are generally those with pointed ends such as sewing needles, toothpicks, and fish bones (4). Sewing needles constitute $2.4 \%$ of FBs swallowed (9). FBs can enter the liver transcutaneously by direct penetration through the abdominal wall, by migration as a result of penetration of the ingested body from the gastrointestinal tract, or through the systemic blood circulation $(5,10)$. Patients who have a FB in the liver can remain asymptomatic for years or have abdominal pain, peritonitis, bleeding, impaired liver function or liver abscess, and related symptoms (11-13).

The subject of removal or follow-up of FBs in the liver is controversial. However, if not removed, they can cause serious complications such as abscess, porto-enteric fistula and bleeding in the liver (14). Therefore, in our patient surgical removal was planned due to the location of the FB-close to the hepatic vein-and the possibility of bleeding as a result of blunt trauma. In the course of the removal of FBs, unnecessary complications can be prevented by determining their location in the tissue or

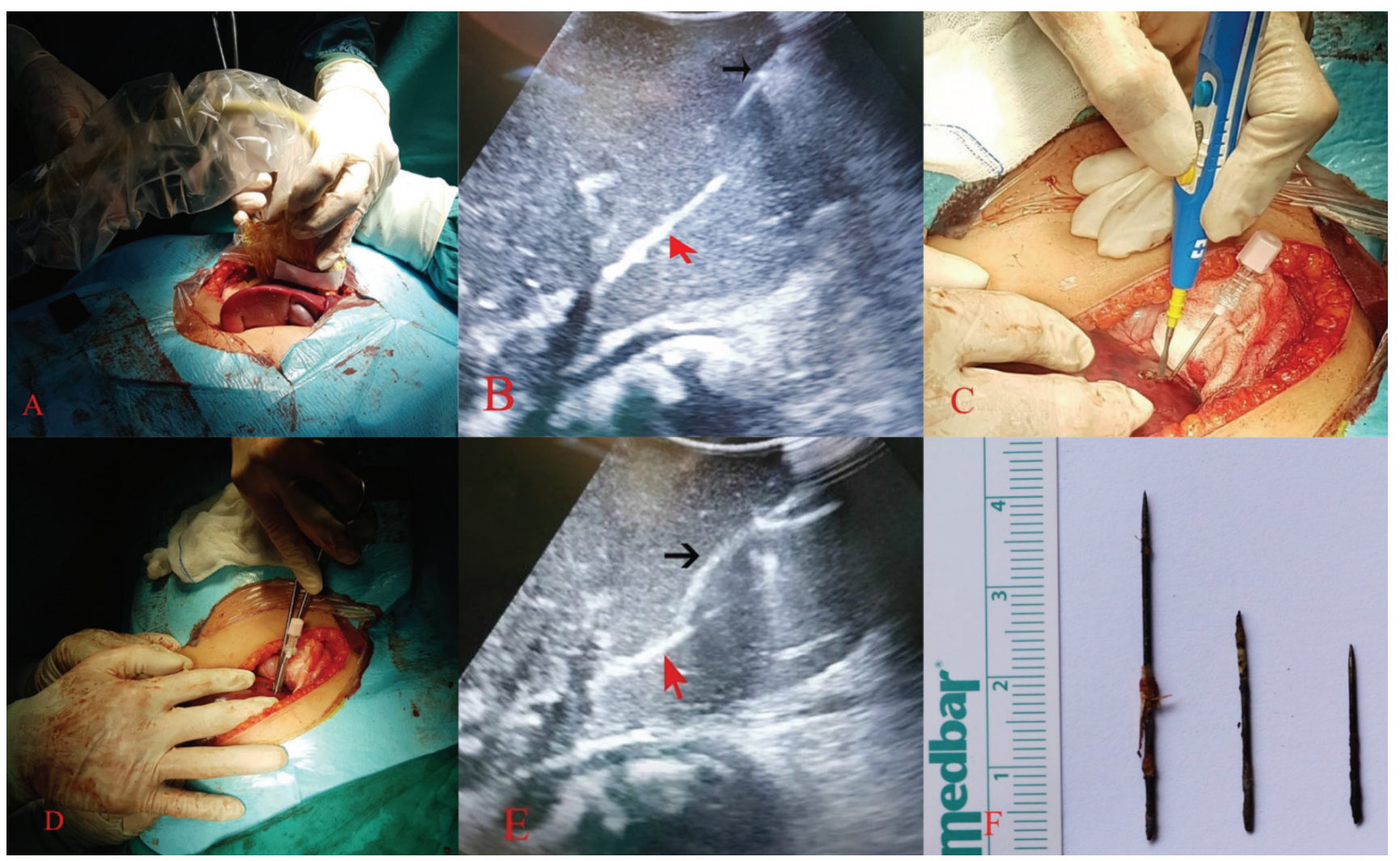

Figure 2. A) Determining the location of the sewing needle by the guidance of US, intraoperatively. B) The localization of the sewing needle (red arrow) was determined with an 18-G biopsy needle (black arrow), with guidance by the US. C) From the lateral side of the biopsy needle, a $1 \mathrm{~cm}$ entry hole was opened in the liver capsule with a cautery. D) A long clamp was inserted through this hole. E) Sewing needle was removed by holding (red arrow) with a clamp (black arrow) accompanied by US. F) All the needles removed are seen side by side. The long needle was removed from the liver. It was seen that the other two pieces removed from the left axillary region were the one-needle divided in the middle. All needles were rusty. This suggests that they entered here a long time ago

US: Ultrasonography 
organ by imaging techniques and marking their location with a catheter, as in our case. Thus, in such patients, using perioperative fluoroscopy or US are recommended $(11,15,16)$. However, we observed that US was more practical and advantageous than fluoroscopy because it can better localize FBs by evaluating them from different aspects when necessary.

It is not properly understood how the two needle pieces we removed from the axillary region settled there. It was assumed that they migrated there either via systemic circulation after penetration from the gastrointestinal tract or settled there as a result of sinking into the axillary region. It has been reported that sharp-tipped FBs such as needles migrate from the gastrointestinal tract to the extra-abdominal organs (e.g. the cervical spine, heart, lungs, submandibular gland, and thyroid) (17-21). However, we could not find an article about migration from the gastrointestinal tract to the axillary region in the English or Turkish literature. Therefore, the second option seems more likely. The mother of the patient also stated that the child liked to play with sewing needles.

The sewing needle located in the left axillary region was also removed with the guidance of US. Localized by an experienced interventional radiologist, the FB was easily removed surgically. We had the experience of removing a large number of FBs from the subcutaneous soft tissues under the guidance of fluoroscopy. It was considered that surgical removal of FB was more easy and less invasive under US guidance.

In conclusion, US is an imaging tool that can be used instead of fluoroscopy to remove FBs from solid organs such as the liver since it does not carry the risk of spreading radiation and is more practical to use. Avoiding radiation risk is very important. Therefore, we recommend using perioperative US to remove FBs both from the liver and from the axillary region.

\section{Authorship Contributions}

Concept: S.D., G.B.I., E.Ş. Design: S.D., G.B.I., M.N.A., E.Ş. Data Collection or Processing: S.D., A.E., V.S.Ş., M.N.A., D.G. Analysis or Interpretation: S.D., G.B.I., M.N.A., E.Ş. Literature Search: S.D., V.S.Ş., C.I.Ö., E.E.E. Writing: S.D., V.S.Ş., E.Ş.

Conflict of Interest: No conflict of interest was declared by the authors.

Financial Disclosure: The authors declared that this study received no financial support.

\section{References}

1. Cheng W, Tam PK. Foreign-body ingestion in children: experience with 1,265 cases. J Pediatr Surg 1999;34:1472-6.

2. Lee $\mathrm{JH}$. Foreign Body Ingestion in Children. Clin Endosc 2018;51:129-36.
3. Smith MT, Wong RK. Foreign bodies. Gastrointest Endosc Clin N Am 2007;17:361-82.

4. Azili MN, Karaman A, Karaman I, et al. A sewing needle migrating into the liver in a child: case report and review of the literature. Pediatr Surg Int 2007;23:1135-7.

5. Xu BJ, Lü CJ, Liu WG, Shu Q, Zhang YB. A sewing needle within the right hepatic lobe of an infant. Pediatr Emerg Care 2013;29:1013-5.

6. Rahalkar MD, Pai B, Kukade G, Al Busaidi SS. Sewing needles as foreign bodies in the liver and pancreas. Clin Radiol 2003;58:84-6.

7. Deveci U, Bakal Ü, Doğan Y. Foreign body in liver: sewing needle. Turk J Gastroenterol 2014;25:737-8.

8. Bostancı O, İdiz UO, Battal M, Kaya C, Mihmanlı M. Case of an intrahepatic sewing needle and review of the literature. Ulus Travma Acil Cerrahi Derg 2017;23:77-80.

9. Dal F, Hatipoglu E, Teksöz S, Ertem M. Foreign body: A sewing needle migrating from the gastrointestinal tract to pancreas. Turk J Surg 2018;34:256-8.

10. Avcu S, Unal O, Ozen O, Bora A, Dülger AC. A swallowed sewing needle migrating to the liver. $N$ Am J Med Sci 2009;1:193-5.

11. Carver D, Bruckschwaiger V, Martel G, Bertens KA, Abou-Khalil J, Balaa F. Laparoscopic retrieval of a sewing needle from the liver: A case report. Int J Surg Case Rep 2018;51:376-8.

12. Sim GG, Sheth SK. Retained Foreign Body Causing a Liver Abscess. Case Rep Emerg Med 2019;2019:4259646.

13. Li J, Zhao D, Lei L, Zhang L, Yu Y, Chen Q. Liver abscess caused by ingestion of fishbone: A case report. Medicine (Baltimore) 2019;98:e16835.

14. Martin S, Petraszko AM, Tandon YK. A case of liver abscesses and porto-enteric fistula caused by an ingested toothpick: A review of the distinctive clinical and imaging features. Radiol Case Rep 2020;15:273-6.

15. Nasri B, Yuu K, Tada M. A case report of successful removal of multiples sewing needles in the gastrointestinal tract and pancreas using intraoperative C-arm fluoroscopy. Int J Surg Case Rep 2016;24:166-71.

16. Yamaguchi N, Hiramatsu K, Shibata Y, et al. Sewing needles in the abdominal cavity assumed to have been ingested and to have penetrated the $\mathrm{Gl}$ tract 40 years ago: A case report. Asian J Endosc Surg 2017;10:446-9.

17. Vesna D, Tatjana A, Slobodan S, Slobodan N. Cardiac tamponade caused by migration of a swallowed sewing needle. Forensic Sci Int 2004;139:237-9.

18. Ozkan Z, Kement M, Kargi AB, et al. An interesting journey of an ingested needle: a case report and review of the literature on extra-abdominal migration of ingested foreign bodies. J Cardiothorac Surg 2011;6:77.

19. Persad ARL, Vitali AM. Migration of a swallowed needle into the cervical spine: case report. J Neurosurg Pediatr 2020:1-3. 
20. Ma J, Sun $Y$, Dai B, Wang $H$. Migration of an Ingested Fish Bone to the Submandibular Gland: A Case Report and Literature Review. Biomed Hub 2019;4:1-4.
21. Wu EH, Huang L, Zhou Y, Zhu X. Migratory Fish Bone in the Thyroid Gland: Case Report and Literature Review. Case Rep Med 2018;2018:7345723. 